\title{
The Relationship of Reserve Account Disclosure Transparency and Accrual Earning Management with Audit Quality as Moderating
}

\section{Latifah binti Nono ${ }^{\bowtie}$ and Siti Khomsatun}

Sekolah Tinggi Ekonomi Islam TAZKIA,

Jl. Ir. H. Djuanda No. 78, Sentul City, Citaringgul, Babakan Madang, Bogor, West Java 16810, Indonesia

DOI: http://dx.doi.org/10.15294/jda.v10i1.13183

Received: 1 February 2018. Revised: 16 February 2018. Accepted: 28 February 2018. Published: 15 March 2018.

\begin{abstract}
The purpose of this study is to examine the effect of transparency of reserve account disclosure on accrual earning management, and also to examine the role of audit quality as a moderator for the effect of transparency of reserve account disclosure on accrual earning management. The population in the study are companies listed on the Indonesia Stock Exchange with a sample period of 2012-2015. The sample selection technique used purposive sampling. The samples were obtained 350 observations of manufacturing companies listed in Indonesia Stock Exchange period 2012 to 2015. This study uses panel regression statistical method with unbalance panel data. The measurements used for Transparency of reserve account disclosure are word count, sentence count, and disclosure index. The results support the hypothesis which show that transparency of reserve account disclosure have negative significant effect on the accrual earning management, audit quality have negative significant effect on accrual earning management, and audit quality has a role as moderator (strengthen) the Negative effect between transparency of reserve account disclosure to accrual earning management.Nevertheless, the result is inconsistent in each model. This study concludes that accrual earning management can be minimized by selecting competent auditors and increasing transparency of accounts receivable accounts.
\end{abstract}

Keywords: allowance and reserve account disclosure; audit quality; accrual earning management

\section{How to cite (APA 6th Style)}

Nono Latifah binti \& Khomsatun, S. (2018). The Relationship of Reserve Account Disclosure Transparency and Accrual Earning Management with Audit Quality as Moderating. Jurnal Dinamika Akuntansi, 10(1), 59-70.

\section{INTRODUCTION}

The relationship between owner or shareholder (principal) and manager (agent) may lead to information imbalance (Asymmetrical Information) caused by ownership of information by managers more widely than the owner. In this case, financial statements are needed as a signal in reducing the problem of information imbalance (Scott, 2015). Financial statements are prepared on the accrual basis (IAI, 2016). The use of accrual basis gives more management flexibility in determining policies that are appropriate to the conditions of the company and gives opportunities for management to manage earnings.

The study finds that reserve accounts can be used by managers in doing earnings management (Cassell, Myers, \& Seidel, 2015; Frank \& Rego, 2006; Kima, 2007). Reserve accounts are also a warning for investors on earnings management behavior (Tuanakotta, 2014). The

Latifah binti Nono $(\bowtie)$

E-mail: latifah.fhae@gmail.com 
judgment of reserve accounts gives flexibility to make earnings management because reserve accounts arises from subjective estimates and is judged to have a more material level (Griffith, Hammersley, \& Kadous, 2015).

The disclosure of reserve accounts is regulated for companies in Indonesia listed in exchanges (Bapepam No KEP-347 / BL / 2012). It aims to provide more transparent information to users. Several previous studies have found evidence of the relationship between disclosure transparency and earnings management. Lobo \& Zhou (2001) give evidence related to the negative effect of financial statement disclosure to earnings management. Cassell et al.(2015) find that accrual earnings management is lower in companies that are transparent in disclosing reserve accounts. Tucker (2015) criticize research conducted by Cassell et al.(2015), namely that the disclosure measurement used only use scale 1 for companies that disclose reserve accounts and 0 otherwise in measuring disclosure transparency, and is assessed as a research weakness by not discriminating the extent of disclosures presented by the company.

Earnings management can be detected through transparency of reserve accounts disclosure, can also be detected through audit quality. External auditor is an independent party that investors trust to detect the existence of earnings management practices (Harahap, 2008). Gerayli, Yanesari, \& Maatoofi (2011); and Rusmin (2010) mention a negative relationship between audit quality and earnings management practices. Some previous studies give empirical evidence about the linkages between audit quality and earnings management by using several different measures (Alzoubi, 2016; Chen, Chen, Lobo, \& Wang, 2011; Houqe, Ahmed, \& van Zijl, 2017; Jordan, Clark, \& Hames, 2010; Miko \& Kamardin, 2015; Rusmin, 2010).

In addition, to be able to correlate directly to reduce the occurrence of earnings management, audit quality can play a role in increasing the negative effect of earnings management disclosure. Among the main objectives to be achieved from audit quality is to improve the quality of management financial reporting (Al-Thuneibat, Issa, \& Baker, 2011). Companies that are audited with good audit quality will be able to encourage management to improve disclosure transparency so as to reduce management in performing earnings management activities. Dita, (2016) conducts a study which finds that disclosure of other comprehensive income is supported by good audit quality through KAP Big-four can reduce earnings management practices for large and small companies. Kirana \& Hasan(2016) find evidence of disclosure level of financial report with good audit quality influences to earnings management

Based on the description, this study aims to examine the effect of reserve accounts disclosure transparency to earnings management. As far as searching, research related to more specific disclosure on reserve accounts has not been done in Indonesia. This study is interesting, although it is required to disclose a reserve accounts, but the level of transparency may be different. In addition, this study aims to examine the moderating effect of audit quality on the effect of reserve accounts disclosures on earnings management. The measurements used are also different to measure the transparency of reserve accounts disclosure. Measurements used are content analysis consisting of word count, sentence count, and disclosure index. These three measurements are based on previous research conducted by Hackston (1996), Suttipun \& Stanton(2012) and Natalia, Gunawan, \& Carolina(2017).

There are two different interests between principal and agent, in which each party seeks to achieve a higher level of prosperity and satisfaction than others. The agency problem can lead to an information imbalance (Asymmetrical Information) caused by ownership of information by managers more widely than owner (Scott, 2015). Moreover, accrual basis is very vulnerable to the judgment of managers that can lead to information gaps. Disclosures typically presented in notes to financial statements (CALK) are considered to be able to minimize information asymmetry.

Disclosure is information provided as an attachment to a financial statement as a footnote or additional. Disclosure is needed by investors to be able to reduce the risk of information it faces. Reduced risk of information can increase the sense of security for investors to invest in securities of certain public companies (Subroto, 2014) and available disclosure must have an element of 
transparency. Disclosures relating to reserve accounts are mandatory disclosures arranged in the decree of the chairman of Bapepam No.KEP-347 / BL / 2012 (Rule VIII.G.7). There are 6 disclosure items consisting of three items of accounts receivable reserve account disclosure, and three items of inventory value decline reserve.

A reserve accounts is one type of accrual that management can use to do earnings management actions (Tuanakotta, 2014). Disclosure of reserve accounts is one of prevention and protection efforts on investor's right to be able to supervise management action. Disclosure of transparent reserve accounts are able to provide more useful information for investors to be able to monitor the actions taken by management (Kima, 2007). Lobo \& Zhou (2001) find that the quality of disclosure negatively affects accrual earning management. Febrininta \& Siregar (2014); and Meini \& Siregar (2014) find that earnings management and disclosure level have a negative relationship. Cassell et al.(2015) find that accrual earnings management is lower in companies with transparent reserve accounts disclosure than companies that disclose non-transparent reserve accounts.

\section{$H_{1}$ : Reserve accounts disclosure transparency negatively affects on Earning management}

In the agency perspective, investor needs to be assured of the content in the financial statements made by the management, ie by auditor. Ratmono (2010) and states that qualified auditors are able to detect earnings management actions done by clients. The quality of audit depends on several factors including auditor's knowledge and the understanding about the company which become auditee and industry run by the company, thus indicating there are industry specifications in the audit. When there are discrepancies in the financial statements assessed, auditor will be able to detect with the competence, experience, and independence they have. Thus, qualified audits can reduce and decrease management opportunities in earning management.

Research shows that the use of auditors with industry specializations can help in reducing earning management behavior because of high audit quality (Christiani \& Nugrahanti, 2014; Gerayli et al., 2011). Johnson, Khurana, \& Reynolds (2002) find that long periods of audit engagement may reduce the level of earnings management. Rahman (2016) find evidence that the duration of audit engagement negatively affect on asymmetric information. An auditor with a tenure of more than three years will gain better knowledge of the business and the client's industry so that it will be able to reduce earnings management that occurs than an auditor with less than two years (Johnson et al., 2002).

\section{$\mathrm{H}_{2}$ : Audit quality negatively affects on Earnings Management}

A qualified audit will provide audit services with professionals which can be accounted for. In performing their duties, the auditor must observe the standards, regulations, and rules concerning matters relating to the annual reports and financial statements of the company. Transparent reserve account disclosure that can reduce earnings management should be reinforced with good audit quality. Several studies have examined the relationship between the effect of the disclosure level on earnings management and moderated by audit quality. Dita (2016) finds that disclosure of Other Comprehensive Income (OCI) supported by audit quality through KAP big-4 may reduce earnings management practices. Kirana \& Hasan (2016) find evidence that the level of of financial statements disclosure with audit quality has an effect on earnings management. All previous research show evidence of financial statement disclosure reinforced by audit quality in reducing earnings management.

$\mathrm{H}_{3}$ : Audit Quality Strengthen the influence of Transparency Disclosure of reserve accounts in reducing earnings management 


\section{RESEARCH METHOD}

This type of research was quantitative with secondary data. The population in the study was companies listed on the Indonesia Stock Exchange with a sample period of 2012-2015. The method of selecting samples by purposive sampling generated 350 units of analysis seen in table 1.

Table 1. Sample Selection

\begin{tabular}{llc}
\hline No & \multicolumn{1}{c}{ Explanation } & Total \\
\hline 1 & Manufacturing Companies listed on Indonesia Stock Exchange (IDX) per year 2015 & 139 \\
2 & Companies listed on IDX year 2007 - 2015 & $(29)$ \\
3 & Companies that used foreign currency & $(22)$ \\
4 & Total Sample & 88 \\
& Observation Period (2012-2015) & 352 \\
& Data not available & $(2)$ \\
& Total Observation & 350 \\
\hline
\end{tabular}

Accrual earning management could be measured by discretionary accruals. This study used modified jones model of Dechow, Sloan, \& Sweeney (1995) which are combined with gains and losses recognition model of Ball \& Shivakumar (2006) as Casell et al. (2015) have done with the following regression model:

TACCit $=\left(\frac{1}{\text { TAit }-1}\right)+\beta 2\left(\frac{\Delta R E V i t-\triangle R E C i t}{\text { TAit }-1}\right)+\beta 3\left(\frac{\text { PPEit }}{\text { TAit }-1}\right)+\beta 4 \frac{\text { CFO }}{\text { TAit }-1}+\beta 5\left(N E G_{\text {CFoit }}\right)+\beta 6\left(N E G_{\text {CFoit }} *\right.$ CFO $)+\varepsilon i t$

With TACC $_{\mathrm{it}}$ : Total Accrual (derived from NI calculations minus CFO), $\triangle$ REV: Changes of earnings of previous year to this year, $\triangle \mathrm{REC}$ : Change of account receivables of previous year to this year, PPE: Gross Property, Plant, Equipment, TAit-1: Total Assets of previous year, CFO: Operating cash flow, NEG_CFO: 1 if CFO less than 0 , and 0 otherwise.

A disclosure was said to be transparent if it presented all the needed and useful information Cassell et al.(2015). In this study, the transparency of accounts receivable reserve disclosure and inventory value decline were measured by three different measures (Suttipun \& Stanton, 2012) and (Natalia et al., 2017): (1) word count, in which measured the disclosure transparency by counting the number of words expressed related to reserve accounts. The calculation of word counts did not include the link words in it. (2) sentence Count, in which measured the disclosure transparency by counting the number of sentences expressed in the reserve accounts. (3) Disclosure index, in which to measure transparency of disclosure by assigning a weighting value to each disclosure item disclosed by the company with a total of disclosure items as many as five items as has been described in the previous discussion.

Audit quality was measured using two different measurements: (1) the auditor of Industrial Specialization and (2) Audit independence. In this study, specialist auditors were measured using market share measure by considering the total assets owned by clients (Gul, Fung, \& Jaggi, 2009). This measurement used dummy variable where 1 if audited by audit specialization, and 0 otherwise.

SPECC $=\frac{\text { Number of KAP clients in the Industry }}{\text { Number of entities in the industry }} \times \frac{\text { the average asset of the KAP client in the industry }}{\text { The average assets of all issuers in the industry }}(2)$

The auditor was said to have an industry specialization if the auditor had a client with a total asset presentation of more than $30 \%$ from the total assets of the entire company in an industry (Reichelt \& Wang, 2010). 
Independence in this study was measured using the period of engagement (Audit Tenure) which was the period of auditor assignment in a company. Tenure was measured based on the measurements in the study of Al-Thuneibat et al.(2011) by calculating the period of KAP assignment in the same company (in years).

\section{TEN $=\Sigma$ The number of years KAP audited the same company}

This study used several control variables: Board of Independent Commissioners, Independent Audit Committee, and Leverage. Previous research mentioned that independent commissioners and audit committees could reduce earnings management (Baxter \& Cotter, 2009). Independent Commissioner was measured by the proportion of the number of independent commissioners present in the company. In this study, independent committee audit was measured by comparing non-executive audit committees to total audit committees. Leverage was positively related to earnings management (Naftalia \& Marsono, 2013). In this study, leverage was measured by dividing total debt with total assets of the company.

Panel data was used, obtained from available documentation in the form of annual reports and corporate finances that have been published by related companies and could be accessed through the website www.idx.co.id, disclosure checklist issued by Bapepam, and audit data that could be accessed via internet. This research used the method of moderation regression. The model produced in this study with the equation as follows:

Model 1:

$E M=\alpha+\beta_{1}$ Trans $A R+\beta_{2}$ TransIn $+\beta_{3}$ Spec $+\beta_{4}$ Tenure $+\beta_{5}$ Trans $A R^{*}$ Spec $+\beta_{6}$ Trans $A R^{*}$ Tenure $++\beta_{7}$ Trans INV ${ }^{*}$ Spec $+\beta_{8}$ Trans INV ${ }^{*}$ Tenure $+\beta_{9}$ Board_Ind $+\beta_{10}$ KomiteAudit_ind $+\beta_{11} D A R+\varepsilon$ (4)

Model 2:

$E M=\alpha+\beta_{1}$ Trans $A L L+\beta_{2}$ Spec $+\beta_{3}$ Tenure $+\beta_{4}$ Trans $A L L^{\star}$ Spec $+\beta_{5}$ Trans $A L L^{\star}$ Tenure $+\beta_{6}$ Board_Ind $+\beta_{7}$ KomiteAudit_ind $+\beta_{8} D A R+\varepsilon$

With EM: Accrual Earning Management, Trans AR: Disclosure transparency of Accounts Receivable, Trans Inv: Transparency of inventory disclosure, Trans ALL: Disclosure transparency of accounts receivable and inventory reserves account (combined both), Spec: Auditor of Industrial Specialization, Tenure: Audit engagement duration, Board_ Ind : Independent Board, Audit Committee_Ind: Independent Audit Committee, DAR: Debt to Asset Ratio. From each research model, for disclosure transparency variable used three different measurements using word count, sentenccount, and disclosure index. So the total model of research in this study was as many as 6 models.

\section{RESULTS AND DISCUSSIONS}

Descriptive statistics in table 2 showed that earnings management had a high range and variation. The company disclosed reserve account of accounts receivable, inventory and combined accounts of both which were measured by index (Transari, Transinvi, Transalli) in accordance with OJK regulations. Average transparency using sentence and word count measures for reserve account of accounts receivable, inventory and combination were not more than 50\%, which meant the company explained the accounts receivable and inventory reserves account in a nutshell. Industrial Specialization Auditor (Spec) indicated that the Spec variable data was not good and not normally distributed. The length of the audit engagement period (Tenure) had the lowest score of 1 and the highest 9 meant that the audit companies conducted audit on the same company for nine consecutive years and the table 2 indicated that the data was good and normally distributed. 
Table 2. Descriptive Statistics

\begin{tabular}{|c|c|c|c|c|c|}
\hline Variables & $\mathbf{N}$ & Mean & Min & $\operatorname{Max}$ & Std.Dev \\
\hline \multicolumn{6}{|c|}{ Earning Management } \\
\hline EM & 350 & 0.0788017 & 0.0000327 & 0.7595517 & 0,0830844 \\
\hline \multicolumn{6}{|c|}{ Transparency of Reserve accounts } \\
\hline Transarw & 350 & 0.4483627 & 0.0438312 & 1 & 0.2149294 \\
\hline Transars & 350 & 0.4427706 & 0.0606061 & 1 & 0.1913726 \\
\hline Transari & 350 & 0.9819048 & 0.6666667 & 1 & 0.075635 \\
\hline Transinvw & 350 & 0.3114723 & 0 & 1 & 0.197167 \\
\hline Transinvs & 350 & 0.3151786 & 0 & 1 & 0.215635 \\
\hline Transinvi & 350 & 0.5028572 & 0 & 1 & 0.2224822 \\
\hline Transallw & 350 & 0.4411631 & 0.0353403 & 1 & 0.1980924 \\
\hline Transalls & 350 & 0.4897857 & 0.05 & 1 & 0.1946521 \\
\hline Transalli & 350 & 0.7404762 & 0.5 & 1 & 0.1262811 \\
\hline \multicolumn{6}{|l|}{ Audit Quality } \\
\hline Spec & 350 & 0.1714286 & 0 & 1 & 0.3774226 \\
\hline Tenure & 350 & 4.034286 & 1 & 9 & 2.385239 \\
\hline \multicolumn{6}{|c|}{ Control Variables } \\
\hline Boardind & 350 & 0.3984572 & 0.17 & 1 & 0.118913 \\
\hline Komaudind & 350 & 0.6470286 & 0.3174807 & 0.25 & 1 \\
\hline Dar & 351 & 0.5096413 & 0.037231 & 2.87629 & 0.3423145 \\
\hline
\end{tabular}

Explanation:

Em

: Total Earning Management used Casell model

Transarw

: Transparency of account receivable disclosure measured by word count

Transars

: Transparency of account receivable disclosure measured by sentence count

Transari

: Transparency of account receivable disclosure measured by index

Transinvw

: Transparency of inventory disclosure measured by word count

Transinvs

: Transparency of inventory disclosure measured by sentence count

Transinvi

: Transparency of inventory disclosure measured by index

Transallw

: Transparency of account receivable and inventory disclosures measured by word count

Transalls

: Transparency of account receivable and inventory disclosures measured by sentence count

Transalli

: Transparency of account receivables and inventory disclosures measured by index

Spec

: Auditor of industrial specialization, measured by using dummy variable, 1 for specialist auditors, 0 otherwise

Tenure : The length of the audit engagement

Boardind : The proportion of independent board of commissioners with total board of commissioners of the company

Komaudind : Proportion of independent audit committee with total independent audit committee

Dar : Debt to Asset Ratio, Total Debt divided by total assets of company 
Tables 3 and 4 showed the best model selection tests for each research model. The hypothesis of this study was tested by using panel data regression analysis. Based on the results of data processing, the hypothesis testing was statistically done by using $\mathrm{t}$ test and $\mathrm{F}$ test.

Table 3. The Results of Hypothesis Testing Model 1

\begin{tabular}{|c|c|c|c|c|c|c|c|}
\hline \multirow{2}{*}{ Variables } & \multirow{2}{*}{ Proxy } & \multicolumn{2}{|c|}{$\mathbf{1 A}$ (word count) } & \multicolumn{2}{|c|}{$\mathbf{1 B}($ sentencecount $)$} & \multicolumn{2}{|c|}{ 1C (index) } \\
\hline & & Coef & tvalue & Coef & tvalue & Coef & tvalue \\
\hline \multirow{2}{*}{$\begin{array}{l}\text { Disclosure } \\
\text { transparency }\end{array}$} & $\begin{array}{l}\text { Accounts receivable } \\
\text { reserve disclosure }\end{array}$ & -0.10546 & 0.007 & -0.141287 & 0.002 & -0.072675 & 0.589 \\
\hline & $\begin{array}{l}\text { Disclosure of inventory } \\
\text { reserves }\end{array}$ & 0.0370721 & 0.395 & 0.0817902 & 0.072 & 0.109811 & 0.008 \\
\hline \multirow[t]{2}{*}{ Audit Quality } & $\begin{array}{l}\text { Auditor of Industrial } \\
\text { Specialization }\end{array}$ & -0.035375 & 0.107 & -0.024742 & 0.604 & -0.220045 & 0.163 \\
\hline & Tenure & -0.004008 & 0.371 & -0.009610 & 0.071 & 0.0153841 & 0.533 \\
\hline \multirow{4}{*}{ Moderation } & Transar ${ }^{\star}$ Spec & 0.0637177 & 0.009 & 0.0685364 & 0.324 & 0.2532174 & 0.108 \\
\hline & Transar*Ten & 0.0017228 & 0.840 & 0.0233674 & 0.019 & -0.014911 & 0.552 \\
\hline & Transinv ${ }^{\star}$ Spec & -0.020619 & 0.398 & -0.066990 & 0.312 & -0.074078 & 0.137 \\
\hline & Transinv ${ }^{\star}$ Ten & 0.0042874 & 0.640 & -0.001310 & 0.889 & -0.005653 & 0.500 \\
\hline \multirow{3}{*}{$\begin{array}{l}\text { Control } \\
\text { Variables }\end{array}$} & Independent Board & -0.071417 & 0.061 & -0.097920 & 0.024 & -0.086556 & 0.022 \\
\hline & $\begin{array}{l}\text { Independent Audit } \\
\text { Committee }\end{array}$ & 0.0091765 & 0.510 & 0.0153628 & 0.368 & 0.0191356 & 0.160 \\
\hline & Debt to Asset Ratio & 0.016517 & 0.207 & 0.025347 & 0.147 & 0.0204639 & 0.149 \\
\hline \multicolumn{2}{|l|}{ F-Statistic } & \multicolumn{2}{|c|}{0.0008} & \multicolumn{2}{|c|}{0.0063} & \multicolumn{2}{|c|}{0.0013} \\
\hline \multicolumn{2}{|l|}{ R-Square } & \multicolumn{2}{|c|}{$8.36 \%$} & \multicolumn{2}{|c|}{$22.57 \%$} & \multicolumn{2}{|c|}{$8,03 \%$} \\
\hline \multicolumn{2}{|l|}{ Adj-R Square } & \multicolumn{2}{|c|}{$5.38 \%$} & \multicolumn{2}{|c|}{$13.43 \%$} & \multicolumn{2}{|c|}{$5,03 \%$} \\
\hline
\end{tabular}

The result of determination coefficient in table 3 for model 1 showed overall dependent variable in the form of earnings management could be explained by independent variable consisting of transparency of accounts receivable reserve disclosure, transparency of inventory reserve disclosure, audit quality, moderation of disclosure transparency and audit quality, along with control variable of 0.0538 or $5.38 \%$ in model $1 \mathrm{~A} ; 0.1343$ or $13.43 \%$ in model $1 \mathrm{~B}$; and 0.0503 or $5.03 \%$ in model $1 \mathrm{C}$. While the rest equal to $94.62 \%$; $86.57 \%$; and $94.97 \%$ were described outside of this model. Despite having low adjusted-R2 value, model 1 had F test value of $0.0008 ; 0.0063$; and 0.0013 which was smaller than 0.05 indicating that the model used in this study was feasible.

Table 4. The Result of Hypothesis Testing of Model 2

\begin{tabular}{|c|c|c|c|c|c|c|c|}
\hline \multirow{2}{*}{ Variables } & \multirow{2}{*}{ Proxy } & \multicolumn{2}{|c|}{$2 \mathrm{~A}($ word count $)$} & \multicolumn{2}{|c|}{ 2B(sentencecount) } & \multicolumn{2}{|c|}{ 2C (Index) } \\
\hline & & Coef & tvalue & Coef & tvalue & Coef & tvalue \\
\hline $\begin{array}{l}\text { Disclosure } \\
\text { Transparency }\end{array}$ & $\begin{array}{l}\text { Disclosures of account } \\
\text { receivables and } \\
\text { inventories reserves } \\
\text { (word count) }\end{array}$ & -0.124970 & 0.004 & -0.098878 & 0.021 & 0.1651883 & 0.026 \\
\hline Audit Quality & $\begin{array}{l}\text { Auditor of Industrial } \\
\text { Specialization }\end{array}$ & -0.076434 & 0.025 & -0.036906 & 0.390 & 0.0287091 & 0.710 \\
\hline & Tenure & -0.005687 & 0.213 & -0.011847 & 0.016 & 0.0109875 & 0.344 \\
\hline Moderation & Transallw*Spec & 0.1430265 & 0.015 & 0.043345 & 0.526 & -0.050097 & 0.594 \\
\hline & Transallw*Ten & 0.0092196 & 0.339 & 0.0215808 & 0.024 & -0.016872 & 0.274 \\
\hline
\end{tabular}




\begin{tabular}{llcccccc} 
Control & Independent Board & -0.075111 & $\mathbf{0 . 0 4 8}$ & -0.075667 & $\mathbf{0 . 0 4 5}$ & -0.083857 & $\mathbf{0 . 0 2 7}$ \\
Variables & Independent Audit & 0.0130664 & 0.350 & 0.0188992 & 0.174 & 0.0192288 & 0.164 \\
& Committee & 0.0172927 & 0.194 & 0.0212719 & 0.106 & 0.0293603 & 0.027 \\
& Debt to Asset Ratio & 0.0017 & & 0.0200 & 0.0177 \\
F-Statistic & & $6.96 \%$ & & $4.93 \%$ & $5.02 \%$ \\
R-Square & & $4,78 \%$ & & $2.70 \%$ & \multicolumn{2}{c}{$2.79 \%$} \\
Adj-R Square & & &
\end{tabular}

Model 2 in table 4, overall dependent variables namely earnings management could be explained by independent variables consisting of transparency disclosure of accounts receivable and inventory reserves, audit quality, transparency moderation and audit quality, along with control variable equal to $4.78 \%$; $2.70 \%$; and $2.79 \%$, while the rest equal to $94.22 \%$; $97.30 \%$; and 97.21\% were described outside of this model. Table 4 showed the F statistic for model 2 was 0.0017 for model 2A; 0.0200 for model 2B; and 0.0177 for model 2C. Each value of F statistics on the three models was at a value smaller than the real level of 0.05 , which meant that the independent variables in this study on each model together affected the earnings management accruals.

Table 5. Summary of Hypothesis Result

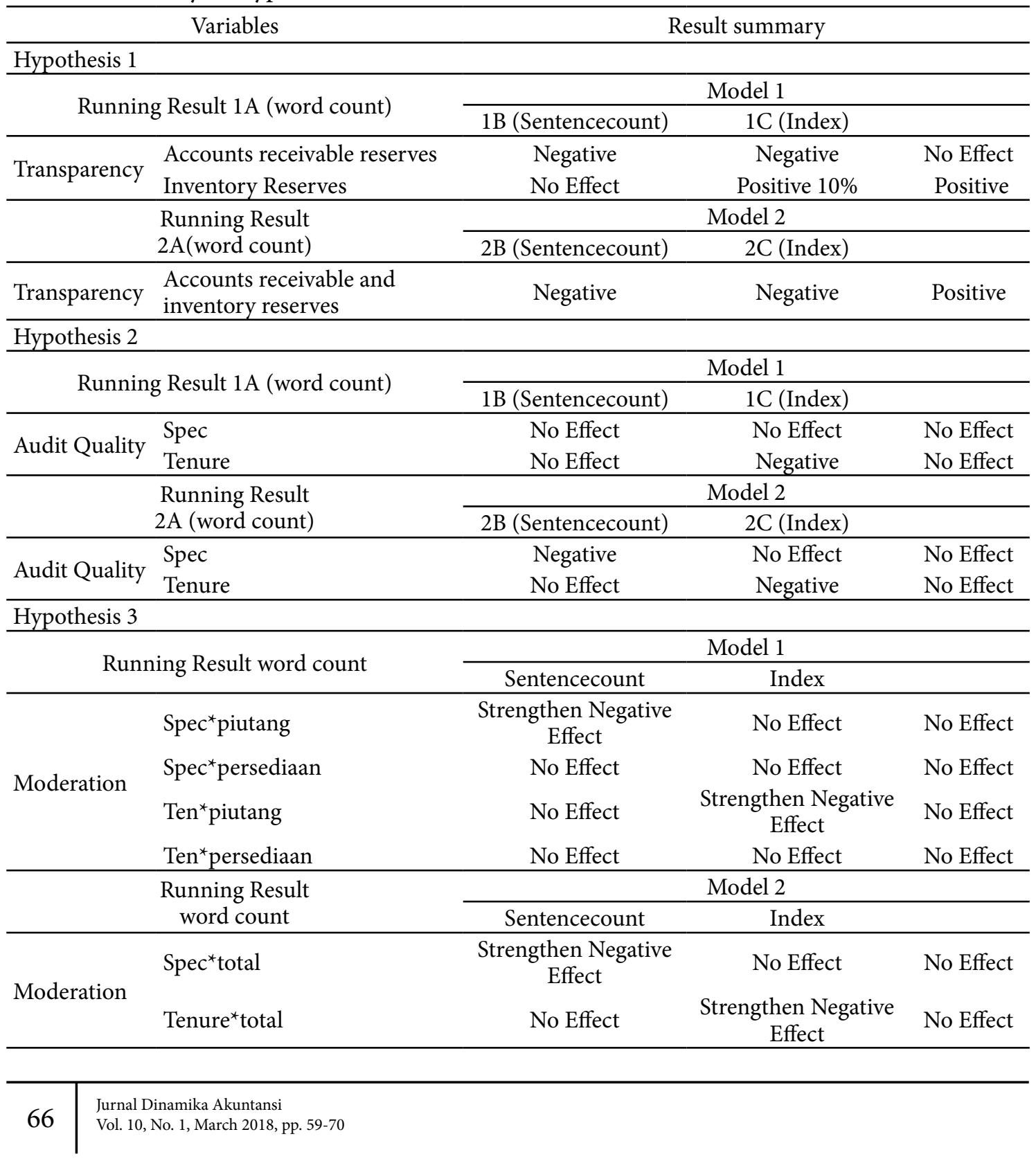


Hypothesis 1 in this study was the transparency of the account receivable reserve disclosure had a negative effect on earning management. Based on table 5, the test result was inconsistent. However, it could be said that when the measurement of disclosure by using sentence and word count there was a negative effect of accounts receivable and inventory reserves disclosure to earnings management. While using Index there was a positive influence of accounts receivable and inventory reserves disclosure to earnings management. This finding suggested the result that measurements using word count and sentence count tended to give better results, since they provided more variation in disclosure than measurements using disclosure Index Maaloul \& Zéghal (2015) which could lower the level of earnings management.

The result of negative influence shown by sentence and word count measurement gave meaning that transparent disclosure could provide better information to investor related behavior done by management, so that will be able to reduce earnings management done by company (Kima, 2007). The result of this study supported the opinion of Healy(1985) who explained that account receivables and inventories were the types of accruals used in the earnings management. These first findings also corresponded to previous study conducted by Cassell et al.(2015), who found that the reserve account disclosure transparency had a negative effect on accrual earning management.

A more detailed explanation made with additional explanations reflected in the number of words and sentences and not merely obeying the regulations could reduce the opportunistic actions of management as it decreased the information asymmetry between managers and investors. In this case, the management or managers of the company had an awareness to disclose information as complete as possible to be accounted to investors as the owner of the company. Thus, the transparency of reserve account disclosure was able to be the owner's control tool on the corporate manager. The research also found evidence that some companies have disclosed accounts receivable and inventory reserves in accordance with the regulations enacted. Thus, mandatory reserve account disclosure did not affect the amount of earnings management conducted by the company. This result was similar to the research undertaken by Frank \& Rego (2006) which found no evidence of the use of reserves in conducting earnings management.

Based on table 5, the second hypothesis showed two findings. First was the negative effect between auditing quality and accrual earning management both measured using the industrial specialization auditor (Aud) and the duration of the audit engagement (Tenure), and the finding that there was no influence between the audit quality and accrual earning management. Second finding that stated it had no effect was seen in the model using the measurement of Index disclosure in measuring transparency of reserves in both the first and second models. As for the first finding, it was found on a model using word count and sentence count measurements.

The first finding was similar to the results of research conducted by Rusmin (2010) and Januarsi (2009) who found the result that accrual discretionary was found to be lower in firms audited by specialized auditors than those who did not have specialization. The reason that industrial specialization auditors (Spec) could reduce earnings management was that industrial specialization auditors had a better understanding of industrial characteristics, more compliance with auditing standards, understanding risks and problems in the industry being audited, and having better error-detecting abilities than industrial non-specialization auditors, so that industrial specialization auditors could better reduce accrual earnings management (Januarsi, 2009). In addition, the first findings supported Ratmono (2010) who said that good qualified auditors were able to ensure the firmness and correctness of financial statements, as well as being able to detect earnings management actions undertaken by the company.

The duration of the audit engagement (tenure) could reduce earnings management, since the auditor gained sufficient understanding on the client and industry's business if the audit period was more than 3 years old compared to the auditor with a shorter assignment period (Johnson et al., 2002). With a better understanding, the auditor was able to detect the possibility of earnings management conducted by the company. This was in accordance with previous research, ie Johnson et al.(2002). Johnson et al. (2002) found that the absolute value of accrual at the time of 
short assignment ( $2-3$ years) was higher than intermediate assignment period ( $4-8$ years). Meutia (2004) gave research results that showed that auditor independence as measured by the duration of audit engagement had negative influence on earnings management.

Sometimes, the quality of a good audit did not affect the actions taken by management in managing the company. The tendency of companies that wanted to look good in the eyes of investors, causing the company to keep doing earnings management regardless of the existence of auditors who audited the company (Luhgiatno,2010), so that the audit quality had no effect to management action in doing earnings management. The results of this study contradicted the hypothesis but in accordance with research conducted by Luhgiatno (2010) and Christiani \& Nugrahanti (2014) who found evidence that the quality of audit had no effect on accrual earning management.

Table 5 showed that the third hypothesis got two findings. The first finding was that audit quality could play a moderating role, which was to strengthen the negative influence between the transparency of reserve account disclosure to accrual earning management. As for the second finding, mentioned that audit quality coyld not play role as moderating variable.

The argument for the first finding was a transparent presentation of account receivable disclosures, providing better information to reduce earnings management compared to nontransparent disclosures. The transparent disclosure of account receivable, supported by good audit quality, would be stronger in reducing accrual earnings management happened to the company. So, audit quality could strengthen the negative transparency of account receivable disclosure to accrual earning management.

This first findings was similar to research conducted by Kirana \& Hasan(2016) which indicated that audit quality could be a moderator of financial statement disclosure to earnings management, Dita (2016) who showed audit quality as measured by KAP measure could strengthen the negative influence of Other Comprehensive Income (OCI) Disclosure on earnings management. This study provided evidence that audit quality could also be moderation, namely it could strengthen the negative effect of reserve account disclosure transparency to accrual earning management.

The argument for the second finding was that the purpose of the auditing itself was not to detect earnings management, but rather to increase the credibility of the financial statements and the reputation of the firm (Liang, Marinovic, \& Varas, 2017; Marinovic, Liang, \& Varas, 2016). So that, there was no influence between the quality of audit provided with earnings management that occurred in the company.

\section{CONCLUSIONS}

The conclusions of this research are (1) transparency of reserve account disclosure proved to have an effect on accrual earning management but with inconsistent result in all models. (2) audit quality proved to have an effect on accrual earning management with inconsistent result in each model. (3) audit quality proved to act as a moderator of transparency effect of reserve account disclosure to accrual earning management, which could strengthen negative influence between transparency of reserve account disclosure to accrual earning management, but inconsistent on each model.

Suggestions that can be given are for academics who want to do research, is expected to examine matters related to the transparency of reserve account disclosure by adding research variables, with a more recent sample period so it can know the progress related to disclosure of reserve account. For the Company, it is expected to be more honest and transparent in providing information related to the reserve account owned. For Investors, to pay attention to the broad range of disclosures related to the account receivables and inventory reserves disclosed by the company on the financial statements. For regulators to be able to encourage and monitor the company to provide information related to the receivables and inventory reserves owned by company. 


\section{REFERENCES}

Al-Thuneibat, A. A., Issa, R. T. I. Al, \& Baker, R. A. A. (2011). Do Audit Tenure And Firm Size Contribute To Audit Quality?: Empirical Evidence From Jordan. Managerial Auditing Journal, 26(4), 317-334.

Alzoubi, E. S. S. (2016). Audit Quality and Earnings Management: Evidence From Jordan. Journal of Applied Accounting Research, 17(2), 170-189.

Ball, R., \& Shivakumar, L. (2006). The Role Of Accruals In Asymmetrically Timely Gain And Loss Recognition. Journal of Accounting Research, 44(2), 207-242.

Baxter, P., \& Cotter, J. (2009). Audit Committees and Earnings Quality. Accounting \& Finance, 49(2), 267290.

Cassell, C. A., Myers, L. A., \& Seidel, T. A. (2015). Disclosure Transparency About Activity In Valuation Allowance And Reserve Accounts and Accruals-Based Earnings Management. Accounting, Organizations and Society, 46, 23-38.

Chen, H., Chen, J. Z., Lobo, G. J., \& Wang, Y. (2011). Effects Of Audit Quality On Earnings Management And Cost Of Equity Capital: Evidence From China. Contemporary Accounting Research, 28(3), 892925.

Christiani, I., \& Nugrahanti, Y. W. (2014). Pengaruh Kualitas Audit Terhadap Manajemen Laba. Jurnal Akuntansi Dan Keuangan, 16(1), 52-62.

Dechow, P. M., Sloan, R. G., \& Sweeney, A. P. (1995). Detecting Earnings Management. Accounting Review, 193-225.

Dita, M. R. (2016). Pengaruh Kualitas Audit Terhadap Hubungan Pengungkapan Other Comprehensive Income dengan Manajemen Laba Pada Perusahaan yang Terdaftar di Bursa Efek Indonesia. Universitas Andalas.

Febrininta, C. N., \& Siregar, S. V. (2014). Manajemen Laba Akrual, Manajemen Laba Riil, dan Biaya Modal. Jurnal Akuntansi Multiparadigma, 5(1), 365-379.

Frank, M. M., \& Rego, S. O. (2006). Do Managers Use The Valuation Allowance Account To Manage Earnings Around Certain Earnings Targets? Journal of the American Taxation Association, 28(1), 43-65.

Gerayli, M. S., Yanesari, A. M., \& Ma'atoofi, A. R. (2011). Impact Of Audit Quality On Earnings Management: Evidence From Iran. International Research Journal of Finance and Economics, 66(1), 77-84.

Griffith, E. E., Hammersley, J. S., \& Kadous, K. (2015). Auditing Complex Estimates: Understanding The Process Used And Problems Encountered. Contemporary Accounting Research, 32(3), 833-863.

Gul, F. A., Fung, S. Y. K., \& Jaggi, B. (2009). Earnings Quality: Some Evidence On The Role Of Auditor Tenure And Auditors' Industry Expertise. Journal of Accounting and Economics, 47(3), 265-287.

Healy, P. M. (1985). The Effect Of Bonus Schemes On Accounting Decisions. Journal of Accounting and Economics, 7(1-3), 85-107.

Houqe, N., Ahmed, K., \& van Zijl, T. (2017). Effects of Audit Quality on Earnings Management and Cost of Equity Capital: Evidence from India. International Journal of Auditing. https://doi.org/10.1111/ ijau. 12087

Januarsi, Y. (2009). Peran Auditor Spesialis Dalam Mengurangi Manajemen Laba Akrual Dan Manajemen Laba Real Pada Periode Sebelum dan Sesudah Keputusan Menteri Keuangan No. 423/KMK. 06/2002. Simposium Nasional Akuntansi, 12.

Johnson, V. E., Khurana, I. K., \& Reynolds, J. K. (2002). Audit-Firm Tenure and The Quality Of Financial Reports. Contemporary Accounting Research, 19(4), 637-660.

Jordan, C. E., Clark, S. J., \& Hames, C. C. (2010). The Impact Of Audit Quality On Earnings Management To Achieve User Reference Points In EPS. Journal of Applied Business Research, 26(1), 19.

Kima, R. (2007). SEC Schedule II-Visibility into the integrity of reported results. AICPA CPA Insider Newsletter. Retrieved from https://www.aicpastore.com/Content/media/PRODUCER_CONTENT/ Newsletters/Articles_2007/CPA/Oct/SEC_Schedule.jsp

Kirana, R., \& Hasan, A. (2016). Pengaruh Tingkat Pengungkapan Laporan Keuangan, Kecakapan Manajerial Dan Risiko Litigasi Terhadap Manajemen Laba Dengan Kualitas Audit Sebagai Variabel Pemoderasi (Studi Empiris Perusahaan Manufaktur Di Bei. Jurnal Akuntansi (Media Riset Akuntansi \& Keuangan), 4(2), 189-205.

Liang, Y., Marinovic, I., \& Varas, F. (2017). The Credibility of Financial Reporting: A Reputation-Based Approach. The Accounting Review, 93(1), 317-333.

Lobo, G. J., \& Zhou, J. (2001). Disclosure Quality and Earnings Management. Asia-Pacific Journal of Accounting \& Economics, 8(1), 1-20. 
Luhgiatno, L. (2010). Analisis Pengaruh Kualitas Audit Terhadap Menejemen Laba Studi Pada Perusahaan Yang Melakukan Ipo Di Indonesia. Fokus Ekonomi, 5(2), 135-146.

Maaloul, A., \& Zéghal, D. (2015). Financial statement informativeness and intellectual capital disclosure: An empirical analysis. Journal of Financial Reporting and Accounting, 13(1), 66-90.

Marinovic, I., Liang, Y., \& Varas, F. (2016). The Credibility of Financial Reporting: A Reputation-Based Approach (Rock Center for Corporate Governance at Stanford University No. 224).

Meini, Z., \& Siregar, S. V. (2014). The Effect of Accrual Earnings Management and Real Earnings Management on Earnings Persistence and Cost of Equity. Journal of Economics, Business \& Accountancy Ventura, 17(2), 269-280.

Meutia, I. (2004). Pengaruh Independensi Auditor Terhadap Manajemen Laba Untuk KAP Big 5 Dan Non Big 5. The Indonesian Journal of Accounting Research, 7(3), 324-336.

Miko, N. U., \& Kamardin, H. (2015). Impact Of Audit Committee And Audit Quality On Preventing Earnings Management In The Pre-And Post-Nigerian Corporate Governance Code 2011. ProcediaSocial and Behavioral Sciences, 172, 651-657.

Naftalia, V. C., \& Marsono, M. (2013). Pengaruh Leverage Terhadap Manajemen Laba Dengan Corporate Governance Sebagai Variabel Pemoderasi. Fakultas Ekonomika dan Bisnis, Diponegoro University.

Natalia, M., Gunawan, Y., \& Carolina, V. (2017). Pengaruh Pengungkapan Tanggung Jawab Sosial Perusahaan terhadap Kinerja Pasar dengan Moderasi Efektifitas Dewan Komisaris dan Independensi Dewan Komisaris. Jurnal Akuntansi, 8(1), 45-64.

Rahman, R. (2016). Pengaruh Kualitas Audit, Tenure Audit Dan Ukuran Perusahaan Terhadap Asimetri Informasi Dengan Komite Audit Sebagai Variabel Pemoderasi (Studi Empiris Pada Perusahaan Manufaktur Periode 2013-2015). FAKULTAS EKONOMI UMY.

Ratmono, D. (2010). Manajemen Laba Riil dan Berbasis Akrual: Dapatkah Auditor yang Berkualitas Mendeteksinya. In Proceeding Simposium Nasional Akuntansi XIII. Purwokerto.

Reichelt, K. J., \& Wang, D. (2010). National And Office-Specific Measures Of Auditor Industry Expertise And Effects On Audit Quality. Journal of Accounting Research, 48(3), 647-686.

Rusmin, R. (2010). Auditor Quality And Earnings Management: Singaporean Evidence. Managerial Auditing Journal, 25(7), 618-638.

Scott, W. R. (2015). Financial Accounting Theory (4th ed.). Canada: Pearson Canada Inc.

Subroto, B. (2014). Faktor-Faktor Yang Mempengaruhi Kepatuhan Kepada Ketentuan Pengungkapan Wajib Oleh Perusahaan-Perusahaan Publik Dan Implikasinya Terhadap Kepercayaan Investor Di Pasar Modal. [Yogyakarta]: Universitas Gadjah Mada.

Suranggane, Z. (2007). Analisis Aktiva Pajak Tangguhan dan Akrual sebagai Prediktor Manajemen Laba: Kajian Empiris pada Perusahaan Manufaktur yang Terdaftar di BEJ. Jurnal Akuntansi Dan Keuangan Indonesia, 4(1), 77-94.

Suttipun, M., \& Stanton, P. (2012). A Study Of Environmental Disclosures By Thai Listed Companies On Websites. Procedia Economics and Finance, 2, 9-15.

Tuanakotta, T. M. (2014). Mendeteksi Manipulasi Laporan Keuangan. Jakarta: Salemba Empat.

Tucker, J. W. (2015). The Relation Between Disclosure Quality And Reporting Quality: A Discussion of Cassell, Myers, and Seidel (2015). Accounting, Organizations and Society, 46, 39-43. 